\title{
Effects of lespedeza condensed tannins alone or with monensin, soybean oil, and coconut oil on feed intake, growth, digestion, ruminal methane emission, and heat energy by yearling Alpine doelings ${ }^{1}$
}

\author{
Haiying Liu, ${ }^{\dagger, \ddagger}$ Richard Puchala, ${ }^{\ddagger}$ Shirron LeShure, ${ }^{\ddagger}$ Terry A. Gipson, \\ Michael D. Flythe," and Arthur L. Goetsch
}

\begin{abstract}
College of Animal Science and Veterinary Medicine, Shenyang Agricultural University, Shenyang 110866,

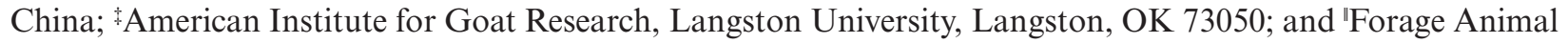
Production Research Unit, ARS, USDA, Lexington, KY
\end{abstract}

\begin{abstract}
Fifty-four Alpine doelings (initial BW and age of $31.7 \pm 0.38 \mathrm{~kg}$ and $306 \pm 1.9 \mathrm{~d}$, respectively) were allocated to nine treatments individually fed for ad libitum intake of $25 \%$ concentrate and $75 \%$ forage diets (DM basis). Alfalfa was the forage in the control diet. Other diets contained Sericea lespedeza as the forage, with $1.25 \% \mathrm{DM}$ of quebracho extract included in the concentrate fraction for a dietary condensed tannin level of $8.4 \%$. Lespedeza treatments were no additive (L) and inclusion of monensin (I) at $22 \mathrm{mg} / \mathrm{kg} \mathrm{DM}$ (L-I), soybean oil at 3\%(L-S), coconut oil at 3\% (L-N), I and 3\% soybean oil (L-I-S), I and 3\% coconut oil (L-I-N), $1.5 \%$ soybean oil and $1.5 \%$ coconut oil (L-S-N), and I, 1.5\% soybean oil, and 1.5\% coconut oil (L-I-S-N). The experiment was $12 \mathrm{wk}$ with two 6-wk periods. Gas exchange was determined in weeks 6 and 12, and other measures occurred in weeks 5 and 11 . The control diet offered averaged $2.67 \%$ nitrogen, $43.8 \%$ neutral detergent fiber, and $8.8 \%$ acid detergent lignin, and the $\mathrm{L}$ diet offered averaged $2.03 \%$ nitrogen, $42.8 \%$ neutral detergent fiber, and $13.2 \%$ acid detergent lignin. There were no treatment $\times$ period interactions for digestibilities $(P \geq 0.770)$ or methane emission $(P \geq 0.324)$.
\end{abstract}

There were differences $(P<0.001)$ between the control treatment and diets with lespedeza in intake of DM (1.46, 1.23, 1.30, 1.18, 1.32, 1.10, 1.02, 1.20, and $1.01 \mathrm{~kg} / \mathrm{d} ; \mathrm{SEM}=0.059)$, digestibility of $\mathrm{OM}$ $(57.4 \%, 50.9 \%, 51.8 \%, 52.7 \%, 50.3 \%, 52.1 \%, 52.1 \%$, $51.9 \%$, and $49.8 \%$; SEM $=1.42$ ), and digestibility of nitrogen $(59.1 \%, 31.2 \%, 32.5 \%, 37.1 \%, 31.6 \%$, $38.3 \%, 30.4 \%, 38.4 \%$, and $34.1 \%$ for control, $\mathrm{L}$, L-I, L-S, L-N, L-I-S, L-I-N, L-S-N, and L-I-S-N, respectively; SEM = 2.21). Ruminal methane emission was less $(P<0.001)$ for diets with lespedeza than for the control in $\mathrm{MJ} / \mathrm{d}(1.36,0.76,0.84,0.71$, $0.71,0.66,0.65,0.68$, and $0.68 ; \mathrm{SEM}=0.048)$ and relative to intake of gross energy $(5.92 \%, 3.27 \%$, $3.49 \%, \quad 3.19 \%, \quad 2.84 \%, \quad 2.91 \%, \quad 3.20 \%, 3.20 \%$, and $3.27 \%$; SEM $=0.165$ ) and digestible energy $(11.19 \%, 6.98 \%, 7.40 \%, 6.38 \%, 5.90 \%, 5.69 \%$, $6.37 \%, 6.38 \%$, and $6.70 \%$ for control, L, L-I, L-S, L-N, L-I-S, L-I-N, L-S-N, and L-I-S-N, respectively; $\mathrm{SEM}=0.400$ ). In conclusion, the magnitude of effect of condensed tannins from lespedeza and quebracho extract on ruminal methane emission by Alpine doelings did not diminish over time and was not markedly influenced by dietary inclusion of monensin, soybean oil, or coconut oil.

Key words: condensed tannins, goats, methane

(C) The Author (s) 2018. Published by Oxford University Press on behalf of the American Society of Animal Science. All rights reserved. For permissions, please e-mail: journals.permissions@oup.com.

J. Anim. Sci. 2019.97:885-899 doi: 10.1093/jas/sky452

\footnotetext{
${ }^{1}$ The project was supported by the USDA National Institute for Food and Agriculture (NIFA), Project OKLUAGOETSCH2014, accession number 1004179. Support for Dr. H. Liu by the China Scholarship Council is acknowledged.
}

${ }^{2}$ Corresponding author: arthur.goetsch@langston.edu Received July 26, 2018.

Accepted November 25, 2018. 


\section{INTRODUCTION}

Climate change is expected to adversely affect future ruminant livestock production (Devendra, 2012), and ruminants emit methane that makes an appreciable contribution to climate change (Johnson and Johnson, 1995; Steinfeld et al., 2006). Moreover, production of methane represents a potential loss of energy to the animal compared with higher ruminal microbial yield of more reduced endproducts, namely propionate, assuming that the responsible intervention does not adversely affect intake or digestion (McGrath et al., 2018). Therefore, it is understandable that much research attention is being given to means of decreasing methane emission by ruminants.

The consumption of condensed tannins, found in many plants such as the leguminous forage lespedeza, has consistently decreased ruminal methane emission by goats (Puchala et al., 2005, 2012a, 2012b, 2018; Animut et al., 2008a, 2008b). There are also other substances that in some instances decrease ruminal methane emission, most notably ionophores, medium chain fatty acids, and long chain polyunsaturated fatty acids (Chalupa, 1980; McAllister et al., 1996). General modes of action of substances affecting ruminal methane emission have not been conclusively identified, although some may be shared and others unique, with potential for interaction. Elucidation of such effects could eventually yield products or identify management practices to achieve greater reductions in methane emission than possible via singular administration. Furthermore, potential for microbial adaptation (Johnson and Johnson, 1995; McAllister et al., 1996; Weimer, 2015; Li et al., 2018) with decreasing effects on methane emission over time could be influenced by simultaneous administration as well. Hence, objectives of the present experiment were to determine effects of condensed tannins of Sericea lespedeza (Lespedeza cuneata) and quebracho extract alone or in combinations with monensin, soybean oil, and coconut oil on feed intake, growth, digestion, ruminal methane emission, and heat energy by yearling Alpine doelings.

\section{MATERIALS AND METHODS}

\section{Animals, Periods, and Housing}

The experimental protocol was approved by the Langston University Animal Care and Use Committee. The study was $12 \mathrm{wk}$ in length, with two 6-wk periods, subsequent to 2 wk for training in use of Calan gate feeders (American Calan, Inc., Northwood, NH). Fifty-four Alpine doelings with an initial BW of $31.7 \pm 0.38 \mathrm{~kg}$ and age of $306 \pm 1.9$ $\mathrm{d}$ were used. The goats were initially assigned to six groups by ranking according to BW and randomly assigning within groups to nine treatments. Thereafter, a small number of treatment assignments were changed to achieve more similar mean BW and variation in BW among the treatments. During the experiment doelings were in six groups with one animal per treatment. The pens were $5.57 \times 3.06 \mathrm{~m}$, consisting of an area of $5.57 \times 1.33$ $\mathrm{m}$ at the front with an elevated expanded metal floor and a flush manure system used once daily. Artificial lighting was provided from 0600 to 1700 hours. Ambient temperature and relative humidity were determined every $30 \mathrm{~min}$ with three Hobo Temperature/RH Data Loggers (model number U12-011; Onset Computer Corp., Bourne, MA) placed in different areas of the facility. Doelings in three pens started the experiment 1 wk before others in three pens. During weeks 6 and 12, doelings resided in metabolism cages for $2 \mathrm{~d}$ of adaptation before being placed in four metabolism cages fitted with head boxes of an indirect, open-circuit respiration calorimetry system for $1 \mathrm{~d}$.

\section{Diets}

Diets were complete mixtures of $25 \%$ concentrate and $75 \%$ forage (Table 1). Forage in the control diet was alfalfa (Medicago sativa), with one-half coarsely ground hay and the other commercially available dehydrated pellets. Forage in the eight other diets was Sericea lespedeza (Lespedeza cuneata), again with 50\% coarsely ground hay and the remaining $50 \%$ commercially available lespedeza pellets (Sims Brothers, Inc., Union Springs, AL). Pelleted lespedeza hay was used in part because the amount of ground hay available was inadequate for the entire study. The lespedeza hay was from a farm in central Arkansas. Before harvest it appeared that the level of lespedeza would be high, but when obtained considerable warm season grasses were present. In addition, to ensure that the level of condensed tannins in the lespedeza diets was moderate to high, a commercially available quebracho extract (Vegetable Tanning Extract, Quebracho Unitan; Tannin Corp., Peabody, MA) was added at $1.25 \%$ DM. Lespedeza treatments included one without any additive (L) and inclusion of monensin (Rumensin 90; Elanco, Greenfield, IN) at $22 \mathrm{mg} / \mathrm{kg}$ DM (L-I), soybean oil (International Ingredient Corp., St. Louis, MO) at 3\% (L-S), coconut oil 
Table 1. Ingredient composition of diets fed to yearling Alpine doelings ( $\%$ DM)

\begin{tabular}{|c|c|c|c|c|c|c|c|c|c|}
\hline \multirow[b]{2}{*}{ Item } & \multicolumn{9}{|c|}{ Treatment $^{1}$} \\
\hline & Control & $\mathrm{L}$ & L-I & L-S & $\mathrm{L}-\mathrm{N}$ & L-I-S & L-I-N & L-S-N & L-I-S-N \\
\hline Coarsely ground alfalfa hay & 37.500 & & & & & & & & \\
\hline Dehydrated alfalfa pellets ${ }^{2}$ & 37.500 & & & & & & & & \\
\hline $\begin{array}{l}\text { Coarsely ground lespedeza } \\
\text { hay }\end{array}$ & & 37.500 & 37.500 & 37.500 & 37.50 & 37.500 & 37.500 & 37.500 & 37.500 \\
\hline Lespedeza pellets ${ }^{3}$ & & 37.500 & 37.500 & 37.500 & 37.50 & 37.500 & 37.500 & 37.500 & 37.500 \\
\hline Quebracho extract ${ }^{4}$ & & 1.250 & 1.250 & 1.250 & 1.250 & 1.250 & 1.250 & 1.250 & 1.250 \\
\hline Rumensin $90^{5}$ & & & 0.011 & & & 0.011 & 0.011 & & 0.011 \\
\hline Soybean oil ${ }^{6}$ & & & & 3.000 & & 3.000 & & 1.500 & 1.500 \\
\hline Coconut oil ${ }^{7}$ & & & & & 3.000 & & 3.000 & 1.500 & 1.500 \\
\hline Rolled corn & 21.820 & 13.930 & 13.909 & 10.279 & 10.279 & 10.263 & 10.263 & 10.279 & 10.248 \\
\hline Soybean meal & & 6.660 & 6.670 & 7.280 & 7.280 & 7.281 & 7.281 & 7.280 & 7.291 \\
\hline Molasses & 2.500 & 2.500 & 2.500 & 2.500 & 2.500 & 2.500 & 2.500 & 2.500 & 2.500 \\
\hline Dicalcium phosphate & 0.080 & 0.060 & 0.060 & 0.091 & 0.091 & 0.095 & 0.095 & 0.091 & 0.100 \\
\hline Vitamin supplement ${ }^{8}$ & 0.500 & 0.500 & 0.500 & 0.500 & 0.500 & 0.500 & 0.500 & 0.500 & 0.500 \\
\hline Mineral supplement ${ }^{9}$ & 0.050 & 0.050 & 0.050 & 0.050 & 0.050 & 0.050 & 0.050 & 0.050 & 0.050 \\
\hline Trace mineral supplement ${ }^{10}$ & 0.050 & 0.050 & 0.050 & 0.050 & 0.050 & 0.050 & 0.050 & 0.050 & 0.050 \\
\hline
\end{tabular}

${ }^{1}$ Control (alfalfa as basal forage); $\mathrm{L}=$ lespedeza as basal forage; $\mathrm{L}-\mathrm{I}=\mathrm{L}$ and the ionophore monensin; $\mathrm{L}-\mathrm{S}=\mathrm{L}$ and soybean oil; $\mathrm{L}-\mathrm{N}=\mathrm{L}$ and coconut oil; L-I-S = L, ionophore, and soybean oil; L-I-N; L, ionophore, and coconut oil; L-S-N = L, soybean oil, and coconut oil; L-I-S-N =L, ionophore, soybean oil, and coconut oil.

${ }^{2}$ Stillwater Milling, Stillwater, OK.

${ }^{3}$ Sims Brothers, Inc., Union Springs, AL.

${ }^{4}$ Tannin Corporation, Peabody, MA.

${ }_{5}^{5} 20 \%$ monensin; Elanco, Greenfield, IN.

${ }^{6}$ International Ingredient Corp., St. Louis, MO.

${ }^{7}$ Butcher Boy, $76^{\circ}$ Coconut Oil \# 550; Columbus Vegetable Oils, Des Plaines, IL.

${ }^{8} 8,800,000 \mathrm{IU} / \mathrm{kg}$ vitamin A, 1,760,000 IU/kg vitamin D3, and 1,100 IU/kg vitamin E; NB-8006, Nutra Blend, Neosho, MO.

${ }^{9}$ Nine percent to $10 \% \mathrm{Ca}, 6 \% \mathrm{P}, 35 \%$ to $40 \% \mathrm{NaCl}, 1 \% \mathrm{Mg}, 1 \% \mathrm{~K}, 1 \% \mathrm{~S}, 125 \mathrm{mg} / \mathrm{kg} \mathrm{Co}, 150 \mathrm{mg} / \mathrm{kg} \mathrm{I}, 5,000 \mathrm{mg} / \mathrm{kg} \mathrm{Fe}, 10 \mathrm{mg} / \mathrm{kg} \mathrm{Se}, 140 \mathrm{mg} / \mathrm{kg}$ $\mathrm{Zn}, 352,000 \mathrm{IU} / \mathrm{kg}$ vitamin A, 88,000 IU/kg vitamin $\mathrm{D}_{3}$, and $330 \mathrm{IU} / \mathrm{kg}$ vitamin E; Stillwater Milling, Stillwater, OK.

${ }^{10}$ Two hundred and seventy-five milligram per kilogram Co, 2,000 mg/kg I, 43,746 mg/kg Fe, 750 mg/kg Se, 18,748 mg/kg Cu, 68,744 mg/kg Zn, and $19,998 \mathrm{mg} / \mathrm{kg} \mathrm{Mn}$.

(Butcher Boy, $76^{\circ}$ Coconut Oil \# 550; Columbus Vegetable Oils, Des Plaines, IL) at 3\% (L-N), $22 \mathrm{mg} /$ $\mathrm{kg}$ of monensin and 3\% soybean oil (L-I-S), $22 \mathrm{mg} /$ $\mathrm{kg}$ of monensin and $3 \%$ coconut oil (L-I-N), $1.5 \%$ soybean oil and $1.5 \%$ coconut oil $(\mathrm{L}-\mathrm{S}-\mathrm{N})$, and $22 \mathrm{mg} / \mathrm{kg}$ monensin, $1.5 \%$ soybean oil, and $1.5 \%$ coconut oil (L-I-S-N). The coconut oil was non-hydrogenated, refined, bleached, and deodorized, and soybean oil was fully refined, bleached, and deodorized as well.

Diets were offered once daily at 0800 hours at $\sim 110 \%$ of consumption on the preceding few days after refusals were collected and weighed. The Calan gate feeders were fitted with Hobo state data loggers that recorded when feeder gates were open and closed. All animals had free access to water and trace mineralized salt blocks (Big 6 Mineral Salt, American Stockman, Overland Park, KS; 96.5\% to $99.5 \% \mathrm{NaCl}, 4,000 \mathrm{mg} / \mathrm{kg} \mathrm{Zn}, 1,600 \mathrm{mg} / \mathrm{kg} \mathrm{Fe}$, $1,200 \mathrm{mg} / \mathrm{kg} \mathrm{Mn}, 260$ to $390 \mathrm{mg} / \mathrm{kg} \mathrm{Cu}, 100 \mathrm{mg} / \mathrm{kg}$ $\mathrm{I}$, and $40 \mathrm{mg} / \mathrm{kg} \mathrm{Co}$; as-fed basis).

\section{Measures}

BW was determined at the beginning, middle, and end of the experiment and on calorimetry measurement days. ADG in each period was determined based on the initial and final BW. Average residual feed intake $(\mathrm{g} / \mathrm{d})$ during the experiment was determined from the difference between actual daily feed intake and expected daily feed intake, which was calculated based on ADG and average $\mathrm{BW}^{0.75}$ during the experiment as described by Basarab et al. (2003). The Kleiber ratio (Kleiber, 1947) was estimated as the ratio of average BW gain to midpoint kilogram $\mathrm{BW}^{0.75}$ (Kelly et al., 2011). Rate of DMI was based on time the Calan gate was open. However, there were some missing observations (seven of 108 potential animal-period observations; 0 to 2 per treatment) as a result of malfunction of the read switch that caused continuous logging of an open or closed state. Two observations of the second period were removed, one because of a leg 
injury and the other low feed intake possibly associated with a health issue.

Ruminal fluid was sampled by stomach tube and blood was collected by jugular venipuncture into heparinized tubes in weeks 4 and 10 on $1 \mathrm{~d}$ at $4 \mathrm{~h}$ after feeding. Plasma was harvested after centrifuging at $3,000 \times g$ and $4{ }^{\circ} \mathrm{C}$ for $20 \mathrm{~min}$ and stored at $-20{ }^{\circ} \mathrm{C}$ until analysis for urea nitrogen (Chaney and Marbach, 1962) and total antioxidant capacity colorimetrically based on a ferric reducing ability of plasma with a Technicon Autoanalyzer II System (Technicon Instruments, Tarrytown, NY; Benzie and Strain, 1996). A portion of ruminal digesta was immediately placed in a sterilized, oxygen-free container for microbiology assays. Other ruminal fluid was measured for $\mathrm{pH}$ with a digital meter. A 3-mL sample was placed in a tube with $2 \mathrm{~mL}$ of $3 \mathrm{M} \mathrm{HCl}$ for ammonia analysis by the procedure of Broderick and Kang (1980). An aliquot of $4 \mathrm{~mL}$ was dispensed into a tube with $1 \mathrm{~mL}$ of $25 \%(\mathrm{w} / \mathrm{v})$ metaphosphoric acid for volatile fatty acid analysis as described by Lu et al. (1990). For protozoa enumeration (Kamra et al., 1991), $1 \mathrm{~mL}$ of ruminal fluid was combined in a tube with $4 \mathrm{~mL}$ of a methyl green, formalin, and saline solution [0.06 g methyl green, $0.85 \mathrm{~g}$ sodium chloride, $10 \mathrm{~mL}$ of $70 \%(\mathrm{v} / \mathrm{v})$ formaldehyde solution, and $90 \mathrm{~mL}$ deionized water].

For ruminal microbial analyses, serial 10-fold dilutions of ruminal fluid were prepared for each sample using the anaerobic dilution solution of Bryant and Burkey (1953). Incubations for total viable bacteria were for $2 \mathrm{wk}$ in roll tubes. The dilution range was $10^{8}$ to $10^{10}$, and there were two replicates for direct count of total viable bacteria determined using the complete medium of Leedle and Hespell (1980). There was $50 \mathrm{~mL}$ of culture media for methanogens (Morvan et al., 1994) dispensed into serum bottles and inoculated with $1 \mathrm{~mL}$ of $10^{4}$-diluted ruminal fluid in duplicate that were incubated for $3 \mathrm{wk}$ to estimate methane production. Methanogenic cultures were pressurized to $202 \mathrm{kPa}$ with $80 \% \mathrm{H}_{2}$ and $20 \%$ $\mathrm{CO}_{2}$. Methane produced in serum bottles was analyzed using an infrared analyzer (MA-1; Sable Systems International, North Las Vegas, NV). The gas mixture from the $150-\mathrm{mL}$ bottles used for incubation of methanogens was transferred into a $250-\mathrm{mL}$ glass syringe and injected at a rate of $400 \mathrm{~mL} / \mathrm{min}$ into the infrared analyzer through a $5 \mathrm{~cm} \times 1.5 \mathrm{~cm}$ column filled with granules of calcium sulfate as a desiccant (WA Hammond Drierite Company, Xenia, $\mathrm{OH}$ ). Ciliate protozoa were enumerated microscopically using a $0.1-\mathrm{mm}$ deep Neubauer hemocytometer counting chamber (Hausser Scientific, Horsham, PA) after fixing with methyl green formalin saline solution.

Total fecal excretion was determined for $6 \mathrm{~d}$ in weeks 5 and 11 with fecal bags having perforated bottoms for urine drainage. Feed was sampled every $2 \mathrm{~d}$ and biweekly composite samples of feedstuffs were formed. Aliquots of feces and orts (about $10 \%$ ) were sampled daily and used to form composites stored at $-20{ }^{\circ} \mathrm{C}$. Partial DM concentration of feed, feed refusals, and feces was first determined by drying in a forced-air oven at $55^{\circ} \mathrm{C}$ for $48 \mathrm{~h}$, and then samples were ground to pass a 1-mm screen. Samples were analyzed for DM, ash (AOAC, 2006), nitrogen (Leco TruMac $\mathrm{CN}$, St. Joseph, MI), gross energy using a bomb calorimeter (Parr 6300; Parr Instrument Co. Inc., Moline, IL), and ether extract concentration with an ANKOM $^{\mathrm{XT15}}$ unit (ANKOM Technology Corp, Fairport, NY; AOCS Official Procedure Am 5-04). In addition, feed was analyzed for neutral detergent fiber (Van Soest et al., 1991) with the addition of a heat-stable $\alpha$ amylase and sodium sulfite, acid detergent fiber, and acid detergent lignin. Detergent fiber assays were determined using an ANKOM200 Fiber Analyzer (filter bag technique; ANKOM Technology Corp.) and were expressed inclusive of residual ash. Feed samples were also analyzed for condensed tannins by the procedure of Dalzell and Kerven (1998), without addition of $\mathrm{Fe}^{3+}$, with inclusion of ascorbic acid, and using condensed tannins extracted from Sericea lespedeza as the standard.

Emission of methane and carbon dioxide and oxygen consumption were measured with an indirect, open-circuit respiration calorimetry system (Sable Systems International) with four head boxes. Oxygen concentration was analyzed using a fuel cell FC-1B oxygen analyzer (Sable Systems International) and methane and carbon dioxide concentrations were measured with infrared analyzers (CA-1B for carbon dioxide and MA-1 for methane; Sable Systems International). Prior to the gas exchange measurements, the validity and accuracy of measures of $\mathrm{CO}_{2}$ emission and $\mathrm{O}_{2}$ uptake were checked through alcohol combustion (average $99.7 \pm 0.7 \%$ and $98.7 \pm 1.1 \%$ of expected $\mathrm{CO}_{2}$ production and $\mathrm{O}_{2}$ consumption, respectively). Also, providing a continuous supply of $0.1 \% \mathrm{CH}_{4}$ in $\mathrm{N}_{2}$ gas to chambers yielded $\mathrm{CH}_{4}$ recovery of $97.8 \pm 0.6 \%$. Before each measurement, analyzers were calibrated with reference gas mixtures $\left(19.5 \%\right.$ and $21.0 \% \mathrm{O}_{2}, 0.5 \%$ and $1.5 \%$ $\mathrm{CO}_{2}$, and $0.1 \%$, and $\left.0.3 \% \mathrm{CH}_{4}\right)$. Heat energy was 
calculated from $\mathrm{O}_{2}$ consumption and production of $\mathrm{CO}_{2}$ and $\mathrm{CH}_{4}$ according to the Brouwer (1965) equation.

Digestibilities were based on feed intake during $6 \mathrm{~d}$ when feces were collected. For energy measures, gross energy digestibility was applied to gross energy intake on $3 \mathrm{~d}$ before and the day of calorimetry measures. Energy loss from ruminal methane emission was based on an energy concentration of $39.5388 \mathrm{~kJ} / \mathrm{L}$ (Brouwer, 1965). Intake of metabolizable energy was estimated by subtracting energy in methane and urine, assumed to be $3 \%$ of gross energy intake (Puchala et al., 2012a, 2012b), from digestible energy. Recovered energy was the difference between metabolizable energy intake and heat energy.

\section{Statistical Analysis}

Data were analyzed using a mixed effects model with SAS (Littell et al. 1998; SAS 2011). Fixed effects were treatment, period, and treatment $\times$ period, with the repeated measure of period and random effect of animal within treatment. Different covariance structures were compared via Akaike's Information Criterion. Values were either lowest for variance components or differences were not marked; therefore, variance components was used. There were some significant effects of period and interactions between treatment and period. Interactions are overviewed but in most cases did not receive appreciable attention since none had marked impact on interpretation or did not involve methane. A model with the repeated measure of period $\times$ hour of the day was used to analyze time spent eating. The model for variables with one value, BW at the beginning and end of the experiment and residual feed intake, had treatment as a fixed effect. Means separation was via eight nonorthogonal contrasts of (i) control treatment vs. others (i.e., forage type), (ii) dietary addition of one supplemental ingredient (L vs. L-I, L-S, and L-N), (iii) addition of an ionophore vs. sources of oil alone (L-I vs. L-S and L-N), (iv) type of oil added alone (L-S vs. L-N), (v) addition of one vs. two supplemental ingredients (L-I, L-S, and L-N vs. L-I-S, L-I-N, and L-S$\mathrm{N}$ ), (vi) addition of an ionophore with a source of oil compared with a mixture of the two sources of oil (L-I-S and L-I-N vs. L-S-N), (vii) type of oil added with an ionophore (L-I-S vs. L-I-N), and (viii) addition of two vs. three supplemental ingredients (L-I-S, L-I-N, and L-S-N vs. L-I-S-N).

\section{RESULTS}

\section{Diet Composition and Environmental Conditions}

Concentrations of neutral detergent fiber and ether extract in the diet offered and DM consumed were affected by period $(P=0.003$ and $<0.001$, respectively) and an interaction between treatment and period ( $P=0.040$ and 0.003 , respectively). However, magnitudes of difference were relatively small and, thus, only treatment means are presented in Table 2. Lespedeza diets offered and consumed were lower in ash and nitrogen contents than the control diet $(P<0.001)$. There were a number of significant contrasts for the concentration of neutral detergent fiber, particularly in DM consumed. The concentration of neutral detergent fiber in the consumed diet ranged from 3.5 to 7.9 percentage units less than in that offered, reflecting some selection against forage and for concentrate. Gross energy concentrations were lower $(P<0.001)$ for the control diet than for diets containing lespedeza because of the difference in the level of ash $(P<0.001)$ in alfalfa and lespedeza, and diets with added oil were expectedly higher in gross energy than other diets. The concentration of acid detergent lignin in DM offered was considerably less $(P<0.001)$ for the control than for lespedeza diets. There were also many significant contrasts for concentrations of ether extract as a result of dietary inclusion of soybean and coconut oils. There were no significant contrasts concerning the level of condensed tannins in lespedeza diets $(P \geq 0.456)$, with values ranging from $7.51 \%$ to $9.01 \%$ of $\mathrm{DM}$. The condensed tannin level in the control diet was not different $(P=0.979)$ from 0 .

Temperature, humidity, and temperature-humidity index were not greatly different between periods (Table 3). It would appear that doelings were not subjected to heat or cold stress conditions (NRC, 2007).

\section{$B W, A D G$, and Feed Intake}

Final BW, ADG, and the Kleiber ratio were less for diets with lespedeza compared with the control $\operatorname{diet}(P=0.030,<0.001$, and $<0.001$, respectively; Table 4). ADG and the Kleiber ratio differed between periods as well ( $P=0.012$ and 0.001 , respectively). DMI was less for lespedeza diets with two additives vs. one $(P=0.002,<0.001$, and $<0.001$ for $\mathrm{g} / \mathrm{d}, \%$ $\mathrm{BW}$, and $\mathrm{g} / \mathrm{kg} \mathrm{BW} \mathrm{BW}^{0.75}$, respectively). The ratio of G:F did not differ among treatments $(P=0.898)$, 
Table 2. Composition of the diet offered to and consumed by yearling Alpine doelings (DM basis)

\begin{tabular}{|c|c|c|c|c|c|c|c|c|c|c|c|}
\hline \multirow[b]{2}{*}{ Item $^{2}$} & \multicolumn{9}{|c|}{ Treatment $^{1}$} & \multirow[b]{2}{*}{ SEM } & \multirow[b]{2}{*}{ Contrast $^{3}$} \\
\hline & $\mathrm{C}$ & $\mathrm{L}$ & L-I & L-S & L-N & L-I-S & L-I-N & L-S-N & L-I-S-N & & \\
\hline \multicolumn{12}{|l|}{$\overline{\text { Offered }}$} \\
\hline Ash, $\%$ & 9.6 & 6.5 & 6.5 & 6.3 & 6.4 & 6.2 & 6.5 & 6.5 & 6.4 & 0.18 & 1 \\
\hline Nitrogen, $\%$ & 2.67 & 2.03 & 1.96 & 2.03 & 2.08 & 2.02 & 2.01 & 1.98 & 1.99 & 0.038 & 1,3 \\
\hline $\mathrm{NDF}, \%$ & 43.8 & 42.8 & 50.1 & 45.4 & 45.9 & 46.6 & 44.6 & 43.3 & 46.3 & 1.54 & 2,3 \\
\hline $\mathrm{ADF}, \%$ & 34.9 & 36.1 & 38.9 & 36.4 & 36.7 & 37.0 & 36.2 & 35.5 & 37.2 & 0.816 & 1,3 \\
\hline ADL, $\%$ & 8.8 & 13.2 & 12.6 & 12.5 & 12.6 & 12.4 & 12.9 & 13.0 & 12.4 & 0.210 & 1,2 \\
\hline Ether extract, $\%$ & 2.21 & 2.48 & 2.06 & 5.15 & 4.82 & 5.00 & 4.50 & 5.58 & 5.47 & 0.206 & $1,2,3,5,6$ \\
\hline $\mathrm{GE}, \mathrm{MJ} / \mathrm{kg}$ & 17.5 & 18.4 & 18.2 & 19.1 & 19.1 & $19.0^{c}$ & $19.0^{c}$ & 19.2 & 19.0 & 0.089 & $1,2,3,5$ \\
\hline $\mathrm{CT}, \%$ & -0.03 & 9.01 & 8.09 & 8.77 & 8.00 & 8.11 & 8.47 & 8.87 & 7.51 & 1.140 & 1 \\
\hline \multicolumn{12}{|l|}{ Consumed } \\
\hline Ash, $\%$ & 9.4 & 6.4 & 6.4 & 6.4 & 6.6 & 6.4 & 6.5 & 6.5 & 6.3 & 0.06 & 1,8 \\
\hline Nitrogen, $\%$ & 2.57 & 1.95 & 1.87 & 2.04 & 2.10 & 2.08 & 1.87 & 1.93 & 1.85 & 0.024 & $1,3,5,7,8$ \\
\hline $\mathrm{NDF}, \%$ & 40.3 & 37.3 & 45.3 & 39.3 & 40.7 & 39.5 & 37.5 & 36.7 & 39.2 & 0.62 & $2,3,5,6,7$ \\
\hline Ether extract, \% & 2.14 & 2.58 & 2.16 & 5.43 & 5.12 & 5.48 & 4.66 & 5.99 & 5.88 & 0.071 & $1,2,3,4,5,6,7,8$ \\
\hline $\mathrm{GE}, \mathrm{MJ} / \mathrm{kg}$ & 17.5 & 18.5 & 18.3 & 19.2 & 19.2 & 19.0 & 19.0 & 19.3 & 19.1 & 0.02 & $1,2,3,5,6$ \\
\hline
\end{tabular}

${ }^{1}$ Control (alfalfa as basal forage); $\mathrm{L}=$ lespedeza as basal forage; $\mathrm{L}-\mathrm{I}=\mathrm{L}$ and the ionophore monensin; $\mathrm{L}-\mathrm{S}=\mathrm{L}$ and soybean oil; $\mathrm{L}-\mathrm{N}=\mathrm{L}$ and coconut oil; L-I-S = L, ionophore, and soybean oil; L-I-N = L, ionophore, and coconut oil; L-S-N = L, soybean oil, and coconut oil; L-I-S-N = L, ionophore, soybean oil, and coconut oil.

${ }^{2} \mathrm{NDF}=$ neutral detergent fiber; $\mathrm{ADF}=$ acid detergent fiber; $\mathrm{ADL}=$ acid detergent lignin; $\mathrm{CT}=$ condensed tannins.

${ }^{3} 1$ = control treatment vs. others; 2 = L vs. L-I, L-S, and L-N; 3 = L-I vs. L-S and L-N; 4 = L-S vs. L-N; $5=$ L-I, L-S, and L-N vs. L-I-S, L-I-N, and L-S-N; 6 = L-I-S and L-I-N vs. L-S-N; 7 = L-I-S vs. L-I-N; 8 = L-I-S, L-I-N, and L-S-N vs. L-I-S-N $(P<0.05)$.

Table 3. Average daily temperature $(T)$, relative humidity (RH), and temperature-humidity index (THI) in the facility in which yearling Alpine doelings were housed

\begin{tabular}{lccccc}
\hline \hline Period & Item & Mean & SEM & Minimum & Maximum \\
\hline 1 & Temperature, ${ }^{\circ} \mathrm{C}$ & 19.8 & 0.08 & 12.9 & 27.8 \\
& $\mathrm{RH}^{\circ} \%$ & 46.2 & 0.30 & 28.5 & 78.4 \\
& THI $^{1}$ & 64.6 & 0.10 & 56.0 & 73.3 \\
2 & Temperature, $^{\circ} \mathrm{C}$ & 18.8 & 0.10 & 9.56 & 30.4 \\
& RH, $\%$ & 54.8 & 0.35 & 21.7 & 83.3 \\
& THI & 63.9 & 0.14 & 51.8 & 76.9 \\
\hline
\end{tabular}

${ }^{1} \mathrm{THI}=(0.8 \times T)+(\mathrm{RH} \times((T-14.3) / 100))+46.3$.

but residual feed intake was greater $(P=0.014)$ for the control diet than for diets containing lespedeza.

The total length of time Calan gates were open, assumed to be eating time, did not differ among treatments $(P=0.391$; Table 4$)$. However, there was an interaction in eating time between treatment and time $(P<0.001$; Figure 1$)$. The primary difference was that control doelings spent much less time eating in the first few hours after the morning feeding compared with doelings fed lespedeza diets. The value for control was less than for the L diet at 0800 hours and those at 0900, 1000, and 1100 hours were least among treatments for control $(P<0.001)$. There was a slight decrease $(P<0.001)$ in time eating from 1000 to 1200 hours for control, but the magnitude of change was minor compared with that for lespedeza treatments. In accordance with the relatively short period of eating time and high DMI for control, rate of DMI was 61\% greater than the average of lespedeza treatments $(P<0.001)$.

\section{Intake and Digestion During Feces Collection}

For the $6 \mathrm{~d}$ when feces were collected, there were some tendencies for interactions among treatment and period for intake of DM, OM, nitrogen, and GE $(P=0.067,0.058,0.063$, and 0.052 , respectively), and there were two variables with $P$-values of 0.046 and 0.043 (i.e., intake of digested DM and $\mathrm{OM}$, respectively). There was no discernible additive(s) responsible for the interactions; therefore, main effect means are presented.

In slight contrast to average DMI during the entire experiment, DMI on fecal collection days was not affected by treatment (contrast $P$-values $\geq$ 0.138; Table 5). Total tract digestibilities of DM, $\mathrm{OM}$, nitrogen, and GE were greater for control than for lespedeza treatments $(P=0.007,<0.001$, $<0.001$, and 0.023 , respectively), with a much greater magnitude of difference in digestibility of nitrogen than other constituents. However, intakes of digested DM, OM, and GE were not influenced by dietary treatment (contrast $P$-values $\geq 0.067$ ). Digestibility of ether extract was lower $(P<0.001)$ for control than for lespedeza treatments. 
Table 4. Effects of forage type and dietary inclusion of monensin and(or) soybean and coconut oils on growth, feed intake, efficiency of feed utilization, and feeding behavior of yearling Alpine doelings

\begin{tabular}{|c|c|c|c|c|c|c|c|c|c|c|c|c|c|c|c|}
\hline \multirow[b]{2}{*}{ Item $^{2}$} & \multicolumn{9}{|c|}{ Treatment $^{1}$} & \multirow[b]{2}{*}{ SEM } & \multirow[b]{2}{*}{ Contrast $^{3}$} & \multicolumn{2}{|c|}{ Period } & \multirow[b]{2}{*}{ SEM } & \multirow[b]{2}{*}{$P$-value } \\
\hline & $\mathrm{C}$ & $\mathrm{L}$ & L-I & L-S & $\mathrm{L}-\mathrm{N}$ & L-I-S & L-I-N & L-S-N & L-I-S-N & & & 1 & 2 & & \\
\hline \multicolumn{16}{|l|}{$\overline{\mathrm{BW}, \mathrm{kg}}$} \\
\hline Initial & 31.8 & 32.2 & 31.2 & 31.6 & 32.3 & 32.0 & 31.3 & 31.4 & 31.3 & 1.24 & & & & & \\
\hline Final & 42.2 & 38.9 & 38.5 & 38.6 & 40.7 & 38.4 & 37.5 & 38.0 & 36.0 & 1.60 & 1 & & & & \\
\hline ADG, $g$ & 124 & 80 & 89 & 84 & 101 & 77 & 74 & 78 & 62 & 9.6 & 1 & 77 & 94 & 3.5 & $<0.001$ \\
\hline $\mathrm{KR}, \mathrm{g} / \mathrm{kg} \mathrm{BW}^{0.75}$ & 8.33 & 5.52 & 6.20 & 5.81 & 6.75 & 5.35 & 5.27 & 5.53 & 4.36 & 0.627 & 1 & 5.56 & 6.24 & 0.233 & 0.001 \\
\hline \multicolumn{16}{|l|}{ DMI } \\
\hline $\mathrm{kg} / \mathrm{d}$ & 1.46 & 1.23 & 1.30 & 1.18 & 1.32 & 1.10 & 1.02 & 1.20 & 1.01 & 0.059 & 1,5 & 1.04 & 1.33 & 0.021 & $<0.001$ \\
\hline BW & 3.96 & 3.49 & 3.50 & 3.35 & 3.62 & 3.13 & 2.95 & 3.23 & 2.99 & 0.108 & 1,5 & 3.11 & 3.61 & 0.041 & $<0.001$ \\
\hline $\mathrm{g} / \mathrm{kg} \mathrm{BW}^{0.75}$ & 97.5 & 85.0 & 85.1 & 81.4 & 88.9 & 76.2 & 71.5 & 78.3 & 72.1 & 2.75 & 1,5 & 74.7 & 88.8 & 1.04 & $<0.001$ \\
\hline $\mathrm{G}: \mathrm{F}, \mathrm{g} / \mathrm{kg}$ & 86.0 & 65.0 & 72.9 & 70.6 & 75.0 & 70.8 & 72.4 & 70.5 & 61.0 & 7.12 & & 73.5 & 69.6 & 2.68 & 0.660 \\
\hline RFI, g & 77.3 & 60.1 & 14.2 & -3.6 & 41.5 & -48.6 & -101.3 & -24.5 & -15.3 & 34.09 & 1 & & & & \\
\hline Eating, $\min / \mathrm{d}$ & 183 & 238 & 240 & 195 & 216 & 198 & 219 & 187 & 209 & 19.9 & & 200 & 217 & 7.8 & 0.021 \\
\hline DMI rate, $\mathrm{g} / \mathrm{min}$ & 8.90 & 5.49 & 5.50 & 6.05 & 6.10 & 5.55 & 4.78 & 6.09 & 4.68 & 0.492 & 1 & 5.51 & 6.30 & 0.181 & $<0.001$ \\
\hline
\end{tabular}

${ }^{1} \mathrm{C}=$ control (alfalfa hay as basal forage) $\mathrm{L}=$ lespedeza as basal forage; $\mathrm{L}-\mathrm{I}=\mathrm{L}$ and the ionophore monensin; $\mathrm{L}-\mathrm{S}=\mathrm{L}$ and soybean oil; $\mathrm{L}-\mathrm{N}=\mathrm{L}$ and coconut oil; L-I-S = L, ionophore, and soybean oil; L-I-N; L, ionophore, and coconut oil; L-S-N = L, soybean oil, and coconut oil; L-I$\mathrm{S}-\mathrm{N}=\mathrm{L}$, ionophore, soybean oil, and coconut oil.

${ }^{2} \mathrm{KR}=$ Kleiber ratio; RFI $=$ residual feed intake.

${ }^{3} 1=$ control treatment vs. others; $5=$ L-I, L-S, and L-N vs. L-I-S, L-I-N, and L-S-N $(P<0.05)$.

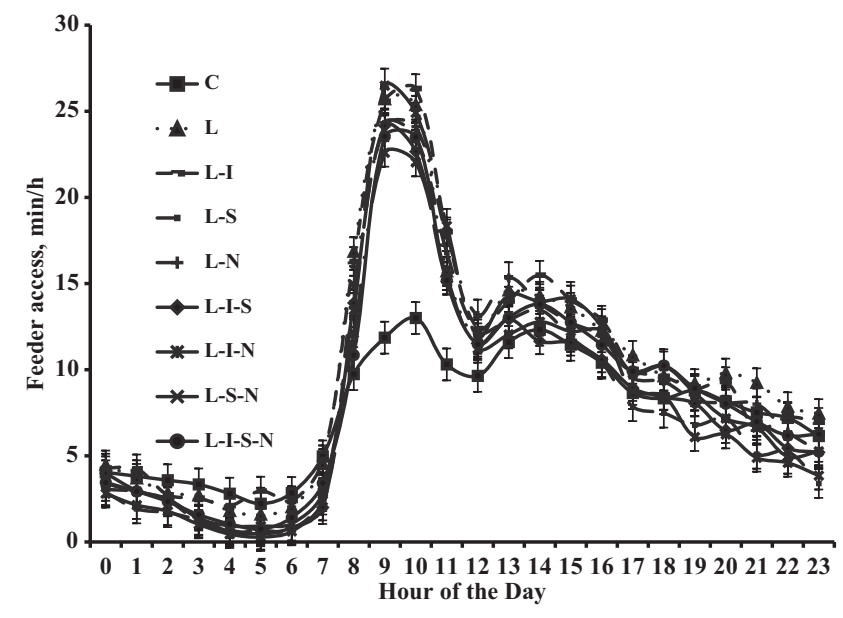

Figure 1. Effects of forage type and dietary inclusion of an ionophore and(or) soybean and coconut oils on feeder access of yearling Alpine doelings. Feed was offered at 0830 hours. $\mathrm{C}=$ control (alfalfa hay as basal forage); $\mathrm{L}=$ lespedeza as basal forage; $\mathrm{L}-\mathrm{I}=\mathrm{L}$ and the ionophore monensin; $\mathrm{L}-\mathrm{S}=\mathrm{L}$ and soybean oil; $\mathrm{L}-\mathrm{N}=\mathrm{L}$ and coconut oil; L-I-S = L, ionophore, and soybean oil; L-I-N = L, ionophore, and coconut oil; L-S-N = L, soybean oil, and coconut oil; L-I-S-N = L, ionophore, soybean oil, and coconut oil. The value for $\mathrm{C}$ was less than for $\mathrm{L}$ at 0800 hours and those at 0900,1000 , and $1100 \mathrm{~h}$ were least among treatments for $\mathrm{C}(P<0.001)$.

Numerous contrasts were significant for intake of total and digested ether extract and for digestibility of ether extract. Ether extract digestibility was greater for diets with lespedeza than for the control diet $(P<0.001)$, which appears related not only to oil inclusion in many lespedeza diets but also greater digestibility of ether extract in lespedeza vs. alfalfa (i.e., L and L-I diets compared with the control).

\section{Energy Measures}

Similar to findings for the days of feces collection (Table 5), intakes of gross energy and digestible energy on the day of calorimetry measures and the preceding $3 \mathrm{~d}$ (Table 6) were not influenced by treatment $(P \geq 0.050)$. The expressions of ruminal methane emission were greater for control than for lespedeza diets $(P<0.001)$, with the average for lespedeza diets being $52.3 \%, 53.6 \%$, and $57.9 \%$ of those for control in $\mathrm{g} / \mathrm{d}$ and as percentages of gross and digestible energy, respectively. Methane emission was slightly less for the mean of L-S and $\mathrm{L}-\mathrm{N}$ diets compared with L-I in $\mathrm{MJ} / \mathrm{d}$ and as percentages of gross and digestible energy $(P=0.028$, 0.024 , and 0.014 , respectively).

Intake of metabolizable energy (Table 6) did not differ among diets in $\mathrm{MJ} / \mathrm{d}$ and $\mathrm{kJ} / \mathrm{kg} \mathrm{BW} \mathrm{BW}^{0.75}$ (contrast $P \geq 0.808$ ). Heat energy in $\mathrm{MJ} / \mathrm{d}$ and $\mathrm{kJ} /$ $\mathrm{kg} \mathrm{BW}^{0.75}$ was greater for control than for lespedeza $\operatorname{diets}(P<0.001$ and $<0.001$, respectively), and contrasts for differences among lespedeza diets were not significant $(P \geq 0.184)$. Recovered energy did not differ among treatments (contrast $P \geq 0.118$ ).

\section{Ruminal Fluid and Blood Measures}

Ruminal fluid $\mathrm{pH}$ was slightly greater for diets with two supplemental ingredients vs. one $(P=0.039$; Table 7$)$. Ruminal ammonia nitrogen concentration was greater for the L-I-S vs. L-I-N treatment $(P=0.032)$. The concentration of total 
Table 5. Effects of forage type and dietary inclusion of monensin (or) soybean and coconut oils on intake and digestion by yearling Alpine doelings during fecal collection

\begin{tabular}{|c|c|c|c|c|c|c|c|c|c|c|c|}
\hline \multirow[b]{2}{*}{ Item } & \multicolumn{9}{|c|}{ Treatment $^{1}$} & \multirow[b]{2}{*}{ SEM } & \multirow[b]{2}{*}{ Contrast $^{2}$} \\
\hline & Control & $\mathrm{L}$ & L-I & L-S & L-N & L-I-S & L-I-N & L-S-N & L-I-S-N & & \\
\hline \multicolumn{12}{|l|}{$\overline{\mathrm{DM}}$} \\
\hline Intake, g/d & 1,214 & 1,246 & 1,242 & 1,176 & 1,294 & 1,170 & 1,140 & 1,146 & 1,024 & 72.1 & \\
\hline Digestibility, \% & 54.8 & 49.7 & 50.4 & 51.6 & 49.4 & 51.4 & 50.9 & 51.3 & 49.0 & 1.44 & 1 \\
\hline Digested, g/d & 663 & 621 & 621 & 609 & 640 & 606 & 576 & 587 & 500 & 43.1 & \\
\hline \multicolumn{12}{|l|}{ OM } \\
\hline Intake, g/d & 1,101 & 1,170 & 1,165 & 1,100 & 1,211 & 1,096 & 1,070 & 1,066 & 959 & 66.9 & \\
\hline Digestibility, \% & 57.4 & 50.9 & 51.8 & 52.7 & 50.3 & 52.1 & 52.1 & 51.9 & 49.8 & 1.42 & 1 \\
\hline Digested, g/d & 629 & 598 & 598 & 583 & 610 & 575 & 553 & 553 & 476 & 40.3 & \\
\hline \multicolumn{12}{|l|}{ Nitrogen } \\
\hline Intake, $\mathrm{g} / \mathrm{d}$ & 31.3 & 25.5 & 24.9 & 25.4 & 27.5 & 24.3 & 22.3 & 25.1 & 20.3 & 1.63 & 1 \\
\hline Digestibility, $\%$ & 59.1 & 31.2 & 32.5 & 37.1 & 31.6 & 38.3 & 30.4 & 38.4 & 34.1 & 2.21 & 1,7 \\
\hline Digested, g/d & 18.5 & 8.00 & 7.94 & 9.37 & 8.66 & 9.44 & 6.69 & 9.61 & 6.90 & 0.854 & 1,7 \\
\hline \multicolumn{12}{|l|}{ Ether extract } \\
\hline Intake, $\mathrm{g} / \mathrm{d}$ & 24.4 & 33.2 & 28.8 & 59.4 & 64.6 & 60.9 & 54.2 & 68.0 & 51.2 & 3.31 & $1,2,3,5,6,8$ \\
\hline Digestibility, $\%$ & 39.1 & 56.5 & 52.9 & 73.0 & 77.6 & 77.7 & 77.3 & 79.9 & 77.1 & 4.74 & $1,2,3,5$ \\
\hline Digested, g/d & 10.7 & 18.9 & 15.2 & 43.2 & 49.8 & 47.3 & 42.3 & 54.3 & 39.6 & 3.24 & $1,2,3,5,6,8$ \\
\hline \multicolumn{12}{|l|}{ Gross energy } \\
\hline Intake, $\mathrm{MJ} / \mathrm{d}$ & 21.1 & 23.1 & 22.7 & 22.4 & 24.6 & 22.6 & 21.8 & 22.0 & 19.5 & 1.36 & \\
\hline Digestibility, \% & 53.3 & 47.7 & 48.1 & 50.6 & 48.6 & 51.1 & 50.7 & 50.9 & 48.8 & 1.50 & 1 \\
\hline Digested, MJ/d & 11.2 & 11.0 & 10.8 & 11.4 & 12.0 & 11.6 & 11.0 & 11.2 & 9.5 & 0.81 & \\
\hline
\end{tabular}

${ }^{1}$ Control (alfalfa hay as basal forage) $\mathrm{L}=$ lespedeza as basal forage; $\mathrm{L}-\mathrm{I}=\mathrm{L}$ and the ionophore monensin; $\mathrm{L}-\mathrm{S}=\mathrm{L}$ and soybean oil; $\mathrm{L}-\mathrm{N}=\mathrm{L}$ and coconut oil; L-I-S = L, ionophore, and soybean oil; L-I-N = L, ionophore, and coconut oil; L-S-N = L, soybean oil, and coconut oil; L-I-S-N = L, ionophore, soybean oil, and coconut oil.

${ }^{2} 1$ = control treatment vs. others; $2=\mathrm{L}$ vs. L-I, L-S, and L-N; 3 = L-I vs. L-S and L-N; 5 = L-I, L-S, and L-N vs. L-I-S, L-I-N, and L-S-N; $6=\mathrm{L}-\mathrm{I}-\mathrm{S}$ and L-I-N vs. L-S-N; 7 = L-I-S vs. L-I-N; $8=\mathrm{L}-\mathrm{I}-\mathrm{S}, \mathrm{L}-\mathrm{I}-\mathrm{N}$, and L-S-N vs. L-I-S-N $(P<0.05)$.

Table 6. Effects of forage type and dietary inclusion of an ionophore and(or) soybean and coconut oils on energy measures of yearling Alpine doelings

\begin{tabular}{|c|c|c|c|c|c|c|c|c|c|c|c|}
\hline \multirow[b]{2}{*}{ Item $^{2}$} & \multicolumn{9}{|c|}{ Treatment $^{1}$} & \multirow[b]{2}{*}{ SEM } & \multirow[b]{2}{*}{ Contrast $^{3}$} \\
\hline & Control & $\mathrm{L}$ & L-I & L-S & L-N & L-I-S & L-I-N & L-S-N & L-I-S-N & & \\
\hline \multicolumn{12}{|l|}{ Gross energy } \\
\hline Intake, $\mathrm{MJ} / \mathrm{d}$ & 23.12 & 23.50 & 24.73 & 22.31 & 25.23 & 22.40 & 20.84 & 21.69 & 20.75 & 1.490 & \\
\hline Digested, $\mathrm{MJ} / \mathrm{d}^{4}$ & 12.36 & 11.24 & 11.84 & 11.23 & 12.25 & 11.48 & 10.54 & 11.08 & 10.25 & 0.820 & \\
\hline Urinary, $\mathrm{MJ} / \mathrm{d}^{5}$ & 0.70 & 0.71 & 0.74 & 0.70 & 0.76 & 0.67 & 0.63 & 0.65 & 0.62 & 0.045 & \\
\hline \multicolumn{12}{|l|}{ Methane } \\
\hline $\mathrm{MJ} / \mathrm{d}$ & 1.36 & 0.76 & 0.84 & 0.71 & 0.71 & 0.66 & 0.65 & 0.68 & 0.68 & 0.048 & $1,3,5$ \\
\hline$\%$ gross energy & 5.92 & 3.27 & 3.49 & 3.19 & 2.84 & 2.91 & 3.20 & 3.20 & 3.27 & 0.165 & 1,3 \\
\hline$\% \mathrm{DE}$ & 11.19 & 6.98 & 7.40 & 6.38 & 5.90 & 5.69 & 6.37 & 6.38 & 6.70 & 0.400 & 1,3 \\
\hline \multicolumn{12}{|l|}{ ME } \\
\hline $\mathrm{MJ} / \mathrm{d}$ & 10.30 & 9.77 & 10.26 & 9.85 & 10.79 & 10.15 & 9.26 & 9.75 & 8.93 & 0.770 & \\
\hline $\mathrm{kJ} / \mathrm{kg} \mathrm{BW}^{0.75}$ & 677 & 668 & 670 & 674 & 723 & 701 & 651 & 678 & 627 & 42.1 & \\
\hline \multicolumn{12}{|l|}{ Heat energy } \\
\hline $\mathrm{MJ} / \mathrm{d}$ & 10.55 & 9.04 & 9.22 & 8.64 & 9.16 & 8.68 & 8.75 & 8.42 & 8.91 & 0.353 & 1 \\
\hline $\mathrm{kJ} / \mathrm{kg} \mathrm{BW}^{0.75}$ & 696 & $619^{a}$ & 632 & 598 & 618 & $600^{\mathrm{a}}$ & 618 & 589 & 625 & 14.7 & 1 \\
\hline $\mathrm{RE}, \mathrm{MJ} / \mathrm{d}$ & -0.25 & 0.73 & 1.04 & 1.21 & 1.63 & 1.47 & 0.51 & 1.33 & 0.06 & 0.549 & 1 \\
\hline
\end{tabular}

${ }^{1}$ Control (alfalfa hay as basal forage) $\mathrm{L}=$ lespedeza as basal forage; $\mathrm{L}-\mathrm{I}=\mathrm{L}$ and the ionophore monensin; $\mathrm{L}-\mathrm{S}=\mathrm{L}$ and soybean oil; $\mathrm{L}-\mathrm{N}=\mathrm{L}$ and coconut oil; L-I-S = L, ionophore, and soybean oil; L-I-N = L, ionophore, and coconut oil; L-S-N = L, soybean oil, and coconut oil; L-I-S-N = L, ionophore, soybean oil, and coconut oil.

${ }^{2} \mathrm{DE}=$ digestible energy $\mathrm{RE}=$ recovered energy.

${ }^{3} 1=$ control treatment vs. others; $3=$ L-I vs. L-S and L-N; $5=$ L-I, L-S, and L-N vs. L-I-S, L-I-N, and L-S-N $(P<0.05)$.

${ }^{4}$ Digestible energy was estimated based on GE intake on $4 \mathrm{~d}(3 \mathrm{~d}$ before and the day of gas exchange measures) and GE digestibility determined during the $6 \mathrm{~d}$ of fecal collection.

${ }^{5}$ Urinary energy was estimated as 3\% of GE intake based on findings of Puchala et al. (2012a,b) 
Table 7. Effects of forage type and dietary inclusion of an ionophore and(or) soybean and coconut oils on ruminal fluid and plasma measures of yearling Alpine doelings

\begin{tabular}{|c|c|c|c|c|c|c|c|c|c|c|c|}
\hline \multirow[b]{2}{*}{ Item } & \multicolumn{9}{|c|}{ Treatment $^{1}$} & \multirow[b]{2}{*}{ SEM } & \multirow[b]{2}{*}{ Contrast $^{2}$} \\
\hline & Control & $\mathrm{L}$ & L-I & L-S & L-N & L-I-S & L-I-N & L-S-N & L-I-S-N & & \\
\hline \multicolumn{12}{|l|}{ Ruminal fluid ${ }^{3}$} \\
\hline $\mathrm{pH}$ & 6.51 & 6.57 & 6.49 & 6.48 & 6.53 & 6.63 & 6.63 & 6.52 & 6.60 & 0.056 & 5 \\
\hline Ammonia $\mathrm{N}, \mathrm{mg} / \mathrm{L}$ & 75.3 & 73.8 & 73.7 & 80.5 & 67.3 & 73.9 & 55.1 & 67.6 & 63.5 & 6.02 & 7 \\
\hline \multicolumn{12}{|l|}{ Volatile fatty acids } \\
\hline Total, $\mathrm{mM} / \mathrm{L}$ & 57.9 & 47.0 & 51.0 & 52.5 & 51.1 & 45.6 & 49.0 & 50.4 & 47.7 & 2.92 & 1 \\
\hline \multicolumn{12}{|l|}{ Molar \% } \\
\hline Acetate & 71.6 & 70.6 & 70.7 & 70.8 & 70.6 & 69.5 & 70.5 & 70.4 & 70.6 & 0.69 & \\
\hline Propionate & 14.5 & 16.8 & 17.4 & 17.6 & 17.2 & 18.2 & 18.1 & 18.9 & 17.7 & 0.99 & 1 \\
\hline Butyrate & 11.8 & 10.8 & 10.1 & 9.7 & 10.4 & 10.1 & 9.8 & 9.2 & 9.9 & 0.52 & 1 \\
\hline Isobutyrate & 0.47 & 0.38 & 0.34 & 0.39 & 0.38 & 0.50 & 0.31 & 0.27 & 0.36 & 0.052 & 6,7 \\
\hline Valerate & 0.99 & 0.89 & 0.90 & 0.97 & 0.97 & 0.92 & 0.90 & 0.92 & 0.87 & 0.066 & \\
\hline Isovalerate & 0.62 & 0.55 & 0.50 & 0.54 & 0.49 & 0.82 & 0.39 & 0.32 & 0.48 & 0.102 & 6,7 \\
\hline A:P ratio & 5.20 & 4.39 & 4.27 & 4.22 & 4.21 & 4.11 & 4.34 & 3.74 & 4.09 & 0.290 & 1 \\
\hline $\begin{array}{l}\text { Total bacteria, } \times 10^{10} / \\
\mathrm{mL}\end{array}$ & 3.50 & 1.16 & 2.90 & 2.94 & 3.02 & 2.04 & 3.15 & 3.24 & 1.19 & 1.003 & \\
\hline Protozoa, $\times 10^{5} / \mathrm{mL}$ & 1.77 & 1.26 & 1.28 & 1.32 & 0.94 & 0.66 & 0.37 & 0.83 & 1.08 & 0.213 & 5 \\
\hline In vitro methane, $\mathrm{mL}^{4}$ & 46.2 & 26.9 & 22.0 & 20.8 & 28.9 & 21.4 & 26.1 & 23.1 & 16.6 & 2.77 & 8 \\
\hline \multicolumn{12}{|l|}{ Plasma } \\
\hline Urea-N, mg/L & 146 & 113 & 141 & 133 & 148 & 135 & 134 & 139 & 129 & 14.4 & \\
\hline $\mathrm{TAC}, \mu \mathrm{M} / \mathrm{L}$ & 172 & 196 & $175^{\mathrm{a}}$ & 224 & 215 & 201 & 190 & 209 & 194 & 9.7 & 3 \\
\hline
\end{tabular}

${ }^{1} \mathrm{C}=$ control (alfalfa hay as basal forage) $\mathrm{L}=$ lespedeza as basal forage; $\mathrm{L}-\mathrm{I}=\mathrm{L}$ and the ionophore monensin; $\mathrm{L}-\mathrm{S}=\mathrm{L}$ and soybean oil; $\mathrm{L}-\mathrm{N}=\mathrm{L}$ and coconut oil; L-I-S = L, ionophore, and soybean oil; L-I-N = L, ionophore, and coconut oil; L-S-N = L, soybean oil, and coconut oil; L-I$\mathrm{S}-\mathrm{N}=\mathrm{L}$, ionophore, soybean oil, and coconut oil.

${ }^{2} 1$ = control treatment vs. others; 3 = L-I vs. L-S and L-N; $5=$ L-I, L-S, and L-N vs. L-I-S, L-I-N, and L-S-N; $6=$ L-I-S and L-I-N vs. L-S-N; 7 = L-I-S vs. L-I-N; 8 = L-I-S, L-I-N, and L-S-N vs. L-I-S-N $(P<0.05)$.

${ }^{3} \mathrm{~N}=$ nitrogen; $\mathrm{A}: \mathrm{P}=$ acetate:propionate; ciliate protozoa; $\mathrm{TAC}=$ total antioxidant capacity.

${ }^{4}$ Incubation of $0.0001 \mathrm{~mL}$ of ruminal fluid in a methanogenic medium for $3 \mathrm{wk}$, with methane production indicative of initial methanogen presence.

volatile fatty acids was greater for the control vs. lespedeza diets $(P=0.008)$. There were no significant contrasts for the molar percentage of acetate, but the level of propionate was greater $(P=0.003)$ and that of butyrate was lower $(P=0.002)$ for diets with lespedeza than for the control diet. There were some relatively small differences in levels of minor volatile fatty acids. The total number of viable bacteria was similar among treatments (contrast $P \geq$ 0.128 ). The number of ciliate protozoa was greater for control than for diets with lespedeza $(P=0.001)$ and the number was less for diets with two supplemental ingredients vs. one as well $(P=0.003)$. In vitro methane production was greater for the control than for lespedeza treatments $(P<0.001)$, with the average of lespedeza diets $50.3 \%$ of production for control. Also, in vitro methane production was less for the L-I-S-N diet than for the mean of L-I-S, L-I-N, and L-S-N treatments $(P=0.047)$. Plasma urea nitrogen did not differ among treatments (contrast $P \geq 0.099$ ). Plasma total antioxidant capacity was greater for diets with lespedeza than for the control $(P=0.008)$, and the value for L-I was less than for the mean of L-S and L-N treatments $(P<0.001)$.

\section{DISCUSSION}

\section{Diet Composition}

Concentrations of some dietary constituents varied slightly among diets based on lespedeza. This could have been because of separation of ingredients between mixing and sampling, variability in sampling in the animal facility and laboratory to form composites, and differences in recovery after grinding of components in original proportions. The level of condensed tannins in lespedeza diets was less than in some in previous studies with goats (i.e., 3\% to 20\%; Animut et al., 2008a, 2008b; Puchala et al., 2012a, 2012b, 2018). With an average condensed tannin level of $8.35 \%$ in lespedeza diets, assuming $76 \%$ condensed tannins in the quebracho extract (Frutos et al., 2004), lespedeza supplied $7.4 \%$ DM of condensed tannins and $89 \%$ of the total. Hence, the average condensed tannin level in 
the two sources of lespedeza, coarsely ground hay and commercially available pellets, was $\sim 10 \%$. The dietary level of condensed tannins in the lespedeza hay used by Puchala et al. (2018), from the same farm but harvested $1 \mathrm{yr}$ earlier, was considerably less at $5.5 \%$. In response, quebracho extract was added to diets in the present experiment to ensure a total dietary condensed tannin level adequate to impact methane emission. Relatedly, results of Animut et al. (2008b) suggest that effects of quebracho condensed tannins on methane emission are similar to those of condensed tannins in lespedeza.

\section{Eating Time, ADG, Feed Intake, and Efficiency of Feed Utilization}

Eating time. It is unclear why much greater proportions of time in the first few hours after feeding were spent eating by doelings on lespedeza treatments than the control, as well as why rate of DMI was lower for diets with lespedeza. However, the lower ratio of acid detergent lignin to neutral detergent fiber in alfalfa vs. lespedeza may have allowed more rapid and extensive particle size reduction during ingestive mastication that lessened time required for boli formation and swallowing. But it should be noted that feed consumption was measured on a daily basis, and differences in rate of intake among hours of the day are possible. Relatedly, in some instances ruminants spend more time eating than necessary based on studies with unrestricted and limited feeder access treatments, which can influence level of performance and efficiency of feed utilization (Tovar-Luna et al., 2011a; Tsukahara et al., 2014; Keli et al., 2017).

It would be interesting to know the number of feeding bouts and meals in different hours of the day. Longer eating time in the first few hours after feed was dispensed by doelings consuming lespedeza diets could have resulted from longer meals or a greater number of meals. Relatedly, with ingestion of some plant secondary metabolites it has been suggested that the number of meals and their frequency may be elevated and the length shortened for conditions to stabilize, such as replenishment of salivary proteins for binding to condensed tannins and(or) liver enzymes to metabolize absorbed toxins (Estell, 2010). Another factor that may have been involved is more extensive sorting and selection of particles of diets with lespedeza than alfalfa, which is supported by a greater difference in the percentage of neutral detergent fiber between DM offered and consumed for diets with lespedeza vs. alfalfa of the control (i.e., 4.8 to 7.9 vs. 3.5 percentage units).
ADG, Feed Intake, and Efficiency of Feed Utilization. It would appear that greater ADG for the control than for lespedeza diets was a consequence of differences in both average DMI during the experiment and digestibility. Application of treatment means of DM digestibility to average DMI resulted in digested DM relatively high for control at $799 \mathrm{~g} / \mathrm{d}$, compared with 612, 620, 605, 652, 566, 517, 575, and $497 \mathrm{~g} / \mathrm{d}$ for L, L-I, L-S, L-N, L-I-S, L-I-N, L-S-N, and L-I-S-N, respectively. Less lignification of fiber of alfalfa than lespedeza may have been responsible for greater digestibility for the control diet than for ones based on lespedeza. Digestibility of neutral detergent fiber was calculated but values are not presented because of some unrealistic estimates relating to use of detergent fractionation procedures with condensed tannin-containing diets identified by Makkar et al. (1995).

Although ADG in period 2 was greater than in period 1 in part because of greater BW, the higher Kleiber ratio in period 2 suggests that greater BW and age were advantageous in regard to the fairly high dietary level of forage and fiber. Treatment differences in residual feed intake but not G:F may relate in part to the consideration of a function of BW in residual feed intake but not gain efficiency. The gain efficiency variable assumes the same amount of feed used for maintenance regardless of ADG and the corresponding average BW within measurement period. Relatedly, residual feed intake during the entire experiment was correlated with average trial DM in $\mathrm{g} / \mathrm{d}(r=0.49 ; P<0.001)$ and G:F $(r=-0.35 ; P=0.012)$ but not with ADG by definition, compared with correlations between G:F and ADG and DMI of $0.87(P<0.001)$ and $0.41(P=0.003)$, respectively.

\section{Digestibility and Ruminal and Blood Constituent Levels}

In studies of this nature in which condensed tannin-containing lespedeza diets are compared with a control based on another forage such as alfalfa or a grass, it can be difficult to definitively determine actual condensed tannin effects on digestibility because of differences in other characteristics. For example, the higher level of fiber lignification in lespedeza vs. alfalfa may have contributed to lower total tract OM digestibility of some lespedeza diets, implying no adverse effects of condensed tannins per se. Similarly, there do not appear to have been negative condensed tannin effects on total tract digestibility in previous experiments (Animut et al., 2008a, 2008b; Puchala et al., 2012a, 2012b) other 
than for nitrogen (Animut et al., 2008a, 2008b; Puchala et al., 2012a, 2012b, 2018).

Based on estimates of true protein digestibility $(88 \%)$ and metabolic fecal CP $(2.67 \%$ DMI) of Moore et al. (2004), nitrogen digestibility means were considerably different than projected. Predicted values were $71.4 \%, 67.1 \%, 66.8 \%, 68.2 \%, 67.9 \%, 67.5 \%$, $66.2 \%, 68.5 \%$, and $66 \%$ for control, L, L-I, L-S, L-N, L-I-S, L-I-N, L-S-N, and L-I-S-N, respectively. Collection of feces in bags with perforated bottoms for urine drainage, with potential retention of some urinary nitrogen in feces, could account for lower than expected digestibility. However, much greater differences between measured and expected values for lespedeza diets than for control suggest impact of condensed tannins through ruminal binding of protein (Robbins et al., 1987; Min et al., 2003; Hoste et al., 2016). As proposed by Puchala et al. (2012a, 2012b, 2018), some protein may have remained bound to condensed tannins after passing from the rumen or rebinding of condensed tannins and protein in the intestines occurred as $\mathrm{pH}$ increased.

From the level of ether extract in DM consumed and ether extract digestibility for the L diet, predicted digestibility of oil ether extract was $89.7 \%$, $99.0 \%, 98.4 \%, 103.6 \%, 97.9 \%$, and $99.6 \%$ for L-S, L-N, L-I-S, L-I-N, L-S-N, and L-I-S-N, respectively. Estimates of $77.2 \%$ and $92.9 \%$ for soybean and coconut oils, respectively, were determined by Puchala et al. (2018) with a basal diet of dehydrated alfalfa pellets consumed by mature Boer goat wethers.

The total concentration of volatile fatty acids is lower than that in some studies with goats but comparable to others. For example, levels in studies investigating effects of lespedeza were 43 to $81 \mathrm{mM} / \mathrm{L}$ (Animut et al., 2008a), 73 to $76 \mathrm{mM} / \mathrm{L}$ (Animut et al., 2008b), and 56 to $83 \mathrm{mM} / \mathrm{L}$ (Puchala et al., 2018). Concentrations in other experiments are 62 to $72 \mathrm{mM} / \mathrm{L}$ in meat goats consuming diets with different levels of supplemental concentrate (Dolebo et al., 2017), 75 to $78 \mathrm{mM} / \mathrm{L}$ for dairy goats in mid-lactation consuming $41 \%$ to $43 \%$ forage diets (Romero-Huelva et al., 2017), and 41 to $64 \mathrm{mM} / \mathrm{L}$ in dairy goats consuming $61 \%$ forage diets (Li et al., 2018). Samples obtained at a greater number of times and with ruminal cannula rather than via stomach tube would provide a more thorough characterization of concentrations of ruminal fluid constituents (Shen et al., 2012).

\section{Energy Measures and Methane}

Methane emission as a percentage of gross energy intake for the control diet of $5.92 \%$ is within the range of $2 \%$ to $15 \%$ observed in cattle (Holter and Young, 1992; Johnson and Johnson, 1995). Moreover, in a study to develop methods of predicting methane emission by goats, Patra and Lalhriatpuii (2016) reported means of $5.25 \%$ and $4.97 \%$ of intake of GE, minimum values of $1.93 \%$ and $1.93 \% \mathrm{GE}$, and maximums of $9.05 \%$ and $8.94 \%$ GE in development and evaluation databases, respectively. Furthermore, values of some previous goat studies with similar procedures for diets without appreciable intake of condensed tannins consumed ad libitum are $13.3 \%$ of intake of GE (Animut et al., 2008a), 3.4\% to 6.1\% GE (TovarLuna et al., 2010a), 2.6\% to 7.1\% GE (Tovar-Luna et al., 2010b), 3.6\% to 4.0\% GE (Tovar-Luna et al., 2011b), 5.8\% to 6.3\% GE (Puchala et al., 2012a), 4.7\% GE (Puchala et al., 2012b), $7.8 \%$ to $9.5 \%$ GE (Tsukahara et al., 2016), 3.1\% to 5.7\% GE (TovarLuna et al., 2017), and 3.1\% GE (Puchala et al., 2018).

The reduction in energy of ruminally emitted methane due to condensed tannins mostly of lespedeza alone or in combination with the other additives of monensin, soybean oil, and coconut oils averaged $42.1 \%$ based on emission by control doelings. The magnitude of change was near the average for condensed tannin sources noted in previous studies of Animut et al. (2008a, 2008b) and Puchala et al. (2012a, 2012b). Although there were small difference in methane emission between the L-I diet and the mean of L-N and L-S diets, overall it does not appear that under these conditions any of the other potential modifiers of methane emission when added to the $\mathrm{L}$ diet alone or with one or more others elicited further reductions.

Assays conducted were not adequate for detailed and conclusive assessment of the mode(s) of action for change in methane emission. Nonetheless, in previous studies direct effects of CT on activity of methanogenic bacteria that may or may not have been associated with decreased protozoal activity have been implicated (Animut et al., 2008a, 2008b; Puchala et al., 2012a, 2012b). Puchala et al. (2018) also noted a similar magnitude of reduction in ruminal methane emission by mature meat goats elicited by condensed tannins of a source of lespedeza, monensin, coconut oil, and soybean oil, with the latter additives added to a basal diet of dehydrated alfalfa pellets rather than lespedeza as in the present experiment. This is despite some presumed differences in modes of action (McAllister et al., 1996; Patra, 2013; Machmüller, 2006; Tomkins et al., 2015). Moreover, even with a relatively low level of condensed tannins in the 
hay used resulting in a total dietary condensed level of $5.5 \%$, a $1: 1$ mixture of lespedeza and alfalfa had a similar effect on ruminal methane emission as a diet without alfalfa. In that experiment, the average reduction in methane emission as a percentage of digestible energy intake for diets with lespedeza and alfalfa containing monensin and the oils compared with alfalfa alone as the basal diet was $32.5 \%$, only slightly less than in the present experiment. Based on results of these two studies, it would be interesting to add an ionophore and oils to diets with relatively low levels of condensed tannins as used by Puchala et al. (2018). That is, dietary level of condensed tannins could influence potential impact of these other substances on ruminal methane emission and other conditions. Lastly, despite only having two periods of measurements separated by $6 \mathrm{wk}$ and a total experiment length of $12 \mathrm{wk}$ in the present experiment, the lack of interaction between treatment and period in measures of methane and others agrees with results of Puchala et al. (2018) indicating little or no microbial adaptation over time to effects of condensed tannins and perhaps to the other dietary additives used as well. This is somewhat in contrast to recent findings of Li et al. (2018) with monensin and nonlactating dairy goats, although DMI was only $1.85 \% \mathrm{BW}$ and the level of monensin was above the recommended level at $32 \mathrm{mg} / \mathrm{kg}$ DMI in that study.

Although there are limitations to procedures in such studies with periods during which feces is collected to determine digestibility and shorter ones at different times to determine gas exchange for energy measures, greater heat and recovered energy for the control than for lespedeza diets bring out some important considerations about evaluating forage utilization. That is, even with the high ratio of acid detergent lignin to neutral detergent fiber in lespedeza, because of reduced methane emission and factors leading to relatively low heat energy, overall feeding value might have been similar to that of alfalfa hay.

\section{Ruminal Fluid and Blood Measures}

The ruminal fluid ammonia nitrogen concentration was lower than expected for diets with these levels of crude protein of $12.3 \%$ to $16.7 \%$ of DM. For the control diet, this may have resulted from less time spent eating in the first few hours after feed was offered compared with lespedeza diets, thus increasing nitrogen capture in microbial protein, as supported by plasma urea nitrogen concentration not different from the lespedeza diets.
The lack of effects of forage type on concentrations of ammonia in ruminal fluid and urea in plasma is not in accordance with decreases noted by Carulla et al. (2005) with tannins of Acacia mearnsii. Likewise, Puchala et al. (2018) noted lower concentrations in yearling meat goats consuming a diet with a high level of lespedeza compared with an alfalfa-based diet; however, levels for a diet with a 1:1 mixture of the forages were not different. Similarly, Puchala et al. (2012a) reported a lower ruminal ammonia concentration in yearling meat goats consuming lespedeza vs. alfalfa hay. Conversely, values for diets of fresh forages did not differ between treatments. As noted in the present experiment, Animut et al. (2008a) found similar ruminal ammonia and plasma urea concentrations in yearling meat goats consuming diets of $100 \%$, $67 \%, 33 \%$, and $0 \%$ lespedeza and corresponding levels of a grass. In each of these studies with lespedeza, total tract nitrogen digestibility decreased with increasing dietary level of lespedeza.

Animut et al. (2008a) presented a plausible explanation for the lack of treatment differences in ruminal ammonia and plasma urea concentrations observed that may be relevant to similar findings in the current study as well. In this previous experiment, urinary nitrogen excretion increased as levels of lespedeza and condensed tannins increased. It was stated that Reed (1995) suggested that by condensed tannins decreasing ruminal ammonia concentration to increase ruminal nitrogen recycling via an increased gradient of urea between plasma and the biofilm environment of urease-producing bacteria adhering to the rumen wall (Cheng and Costerton, 1980), condensed tannins may increase efficiency of nitrogen recycling to the rumen. Moreover, the glycoprotein content of saliva (Reed, 1995) and quantity of saliva produced may be increased by condensed tannins (Van Soest, 1994).

Numerically lower numbers of protozoa for lespedeza diets than for control is somewhat in agreement with previous experiments with lespedeza condensed tannins (Animut et al., 2008a, 2008b; Puchala et al., 2012a, 2012b). The average reduction in in vitro methane production for lespedeza diets (i.e., $50 \%$ ) was similar to that in vivo relative to gross energy intake (48\%). Generally, in previous experiments condensed tannin effects were similar in vivo and in vitro (Animut et al., 2008a; Puchala et al., 2012a), but in some cases reductions in vivo were slightly greater magnitude (Animut et al., 2008b).

Goetsch (2016) summarized that there is interest in dietary means of increasing antioxidant capacity 
because of incomplete scavenging of generated reactive oxygen species that elevates oxidative stress to adversely affect conditions such as immunity. Though not conclusive, plasma total antioxidant capacity levels in the present experiment suggest some potential for increased antioxidant status through dietary inclusion of soybean and coconut oils and perhaps condensed tannins of lespedeza as well. These findings warrant future research more specifically designed to address this aspect.

In conclusion, ruminal methane emission by yearling Alpine doelings consuming 75\% forage diets of lespedeza alone or with monensin, soybean oil, and coconut oil added alone or together, with an average condensed tannin level in lespedeza and quebracho extract diets of $8.4 \%$, averaged $42 \%$ lower than of alfalfa. Under these conditions the effect of condensed tannins on ruminal methane emission was not markedly altered by simultaneous dietary inclusion of an ionophore or sources of medium chain fatty acids or long chain polyunsaturated fatty acids. Moreover, with a 12-wk experiment length and gas exchange measures in weeks 6 and 12, treatment effects on methane emission were consistent, indicating a lack of microbial adaptation over time to factors impacting methane emission.

\section{Conflict of interest statement. None declared.}

\section{LITERATURE CITED}

Animut, G., R. Puchala, A. L. Goetsch, A. K. Patra, T. Sahlu, V. H. Varel, and J. Wells. 2008a. Methane emission by goats consuming diets with different levels of condensed tannins from lespedeza. Anim. Feed Sci. Technol. 144:212-227. doi:10.1016/j.anifeedsci.2007.10.014

Animut, G., R. Puchala, A. L. Goetsch, A. K. Patra, T. Sahlu, V. H. Varel, and J. Wells. 2008b. Methane emission by goats consuming different sources of condensed tannins. Anim. Feed Sci. Technol. 144:228-241. doi:10.1016/j. anifeedsci.2007.10.015

AOAC. 2006. Official methods of analysis. 18th ed. Gaithersburg, MD: AOAC International.

Basarab, J. A., M. A. Price, J. L. Aalhus, E. K. Okine, W. M. Snelling, and K. L. Lyle. 2003. Residual feed intake and body composition in young growing cattle. Can. J. Anim. Sci. 83:189-204. doi:10.414/A02-065

Benzie, I. F. F., and J. J. Strain. 1996. The ferric reducing ability of plasma (FRAP) as a measure of "antioxidant power": the FRAP assay. Anal. Biochem. 239:70-76. doi: 10.1006/ abio. 1996.0292

Broderick, G. A., and J. H. Kang. 1980. Automated simultaneous determination of ammonia and total amino acids in ruminal fluid and in vitro media. J. Dairy Sci. 63:64-75. doi:10.3168/jds.S0022-0302(80)82888-8

Brouwer, E. 1965. Report of sub-committee on constants and factors. In: K. L. Blaxter, editor, Energy metabolism.
Proceedings of the 3rd Symposium European Association of Animmal Production. Publication No. 11. London, UK: Academic Press; p. 441-443. NII Article ID:10024586829.

Bryant, M. P., and L. A. Burkey. 1953. Cultural methods and some characteristics of some numerous groups of bacteria in the bovine rumen. J. Dairy Sci. 36:205-217. doi:10.3168/ jds.S0022-0302(53)91482-9

Carulla, J. E., M. Kreuzer, A. Machmüller, and H. D. Hess. 2005. Supplementation of Acacia mearnsii tannins decreases methanogenesis and urinary nitrogen in forage-fed sheep. Aust. J. Agric. Res. 56:961-970. doi:10.1071/AR05022

Chalupa, W. 1980. Chemical control of rumen microbial metabolism. In: Y. Ruckebusch, and P. Thivend, editors, Digestive physiology and metabolism in ruminants. Westport, CT: AVI Publishing; p. 325-347. doi:10.1007/978-94-011-8067-2_16

Chaney, A. L., and E. P. Marbach. 1962. Modified reagents for determination of urea and ammonia. Clin. Chem. 8:130-132.

Cheng, K. -J., and J. W. Costerton. 1980. Adherent rumen bacteria - their role in the digestion of plant material, urea and epithelial cells. In: Y. Ruckebush, and P. Thivend, editors, Digestive physiology and metabolism in ruminants. , Westport, CT: AVI Publishing; p. 227-250. doi:10.1007/978-94-011-8067-2_11

Dalzell, S. A., and G. L. Kerven. 1998. A rapid method for the measurement of Leucaena spp. proanthocyanidins by the proanthocyanidin (butanol/ $\mathrm{HCl}$ ) assay. J. Sci. Food. Agric. 78:405-416. doi:10.1002/ (dici)1097-0010(199811)78:3<405::aid-jsfa133>3.0.co;2-g

Devendra, C. 2012. Climate change threats and effects: challenges for agriculture and food security. Perpustakaan Negara, Malaysia: Academy of Sciences Malaysia. https://www.agrilinks.org/sites/default/files/resource/files/ climate_change_threats_effects_strategies.pdf

Dolebo, A. T., R. Puchala, T. A. Gipson, L. J. Dawson, T. Sahlu, and A. L. Goetsch. 2017. Effects of supplemental concentrate level and forage source on intake and digestion by growing and yearling Boer goat wethers and evaluation of a method of predicting negative feedstuff associative effects. J. Appl. Anim. Res. 45:470-479. doi:10 .1080/09712119.2016.1217867

Estell, R. E. 2010. Coping with shrub secondary metabolites by ruminants. Small Rumin. Res. 94:1-9. doi:10.1016/j. smallrumres.2010.09.012

Frutos, P., G. Hervas, F. J. Giraldez, and A. R. Mantecon. 2004. An in vitro study on the ability of polyethylene glycol to inhibit the effect of quebracho tannins and tannic acid on rumen fermentation in sheep, goats, cows, and deer. Aust. J. Agric. Res. 55:1125-1132. doi:10.1071/AR04058

Goetsch, A. L. 2016. Current areas of research of feeding practices for lactating goats. Prof. Anim. Scientist 32:725-735. doi:10.15232/pas.2016-01541

Holter, J. B., and A. J. Young. 1992. Methane production in dry and lactating Holstein cows. J. Dairy Sci. 75:2165-2175. doi:10.3168/jds.S0022-0302(92)77976-4

Hoste, H., J. F. Torres-Acosta, J. Quijada, I. Chan-Perez, M. M. Dakheel, D. S. Kommuru, I. Mueller-Harvey, and T. H. Terrill. 2016. Interactions between nutrition and infections with Haemonchus contortus and related gastrointestinal nematodes in small ruminants. Adv. Parasitol. 93:239-351. doi:10.1016/bs.apar.2016.02.025 
Johnson, K. A., and D. E. Johnson. 1995. Methane emissions from cattle. J. Anim. Sci. 73:2483-2492. doi:10.2527/1995.7382483x

Kamra, D. N., R. K. Sawal, N. N. Pathak, N. Kewalrammani, and N. Agrawal. 1991. Diurnal variations in ciliate protozoa in the rumen of blackbuck (Antilope cervicapra) fed green forages. Lett. Appl. Microbiol. 13:165-167. doi:10.1111/j.1472-765x.1991.tb00598.x

Keli, A., L. P. S. Ribeiro, T. A. Gipson, R. Puchala, K. Tesfai, Y. Tsukahara, T. Sahlu, and A. L. Goetsch. 2017. Effects of pasture access regime on performance, grazing behavior, and energy utilization by Alpine goats in early and mid-lactation. Small Rumin. Res. 154:58-69. doi:10.1016/j.smallrumres.2017.07.004

Kelly, A. K., M. McGee, D. H. Crews, Jr., C. O. Lynch, A. R. Wylie, R. D. Evans, and D. A. Kenny. 2011. Relationship between body measurements, metabolic hormones, metabolites and residual feed intake in performance tested pedigree beef bulls. Livest. Sci. 135:8-16. doi:10.1016.j.livsci.2010.05.018

Kleiber, M. 1947. Body size and metabolic rate. Physiol. Rev. 27:511-541. doi:10.1152/physrev.1947.27.4.511

Leedle, J. A. Z., and R. C. Hespell. 1980. Differential carbohydrate media and anaerobic replica plating techniques in delineating carbohydrate-utilizing subgroups in rumen bacteria populations. Appl. Environ. Microbiol. 34:709719. PMID: 6769390.

Li, Z. J., H. Ren, S. M. Liu, C. J. Cai, J. T. Han, F. Li, and J. H. Yao. 2018. Dynamics of methanogenesis, ruminal fermentation, and alfalfa degradation during adaptation to monensin supplementation in goats. J. Dairy Sci. 101:1048-1059. doi:10.3168/jds.2017-13254

Littell, R. C., P. R. Henry, and C. B. Ammerman. 1998. Statistical analysis of repeated measures data using SAS procedures. J. Anim. Sci. 76:1216-1231.doi:1998.7641216x

Lu, C. D., M. J. Potchoiba, T. Sahlu, and J. M. Fernandez. 1990. Performance of dairy goats fed isonitrogenous diets containing soybean meal or hydrolyzed feather meal during early lactation. Small Rumin. Res. 3:425-434. doi:10.1016/0921-4488(90)90073-f

Machmüller, A. 2006. Medium-chain fatty acids and their potential to reduce methanogenesis in domestic ruminants. Agric. Ecosyst. Environ. 112:107-114. doi:10.1016/j. agee.2005.08.010

Makkar, H. P. S., N. K. Borowy, K. Becker, and A. Degen. 1995. Some problems in fiber determination of a tannin-rich forage (Acacia saligna leaves) and their implications in in vivo studies. Anim. Feed Sci. Technol. 55:67-76. doi:10.1016/0377-8401(95)00793-m

McAllister, T. A., E. K. Okine, G. W. Mathison, and K.J. Cheng. 1996. Dietary, environmental and microbiological aspects of methane production in ruminants. Can. J. Anim. Sci. 76:231-243. doi:10.4141/cjas-2014-074

McGrath, J., S. M. Duval, L. F. M. Tamassia, M. Kindermann, R. T. Stemmler, V. N. de Gouvea, T. S. Acedo, I. Immig, S. N. Williams, and P. Celi. 2018. Nutritional strategies in ruminants: a lifetime approach. Res. Vet. Sci. 116:28-39. doi:10.1016/j.rvsc.2017.09.011

Min, B. R., T. N. Barry, G. T. Attwood, and W. C. McNabb. 2003. The effect of condensed tannins on the nutrition and health of ruminants fed fresh temperate forages: a review. Anim. Feed Sci. Technol. 106:3-19. doi:10.1016/ S0377-8401(03)00041-5
Moore, J. E., A. L. Goetsch, J. Luo, F. N. Owens, M. L. Galyean, Z. B. Johnson, T. Sahlu, and C. L. Ferrell. 2004. Prediction of feed crude protein excretion of goats. Small Rumin. Res. 53:275-292. doi:10.1016/j.smallrumres.2004.04.008

Morvan, B., J. Dore, F. Rieu-Lesme, L. Foucat, G. Fonty, and P. Gouet. 1994. Establishment of hydrogen-utilizing bacteria in the rumen of the newborn lamb. FEMS Microbiol. Lett. 117:249-256. doi:10.1111/j.1574-6968.1994. tb06775.x

NRC. 2007. Nutrient requirements of small ruminants. Sheep, goats, cervids, and new world camelids. Washington, DC: National Academic Press. doi:10.17226/11654

Patra, A. K. 2013. The effect of dietary fats on methane emissions, and its other effects on digestibility, rumen fermentation and lactation performance in cattle: a meta-analysis. Livest. Sci. 155:244-254. doi:10.1016/j.livsci.2013.05.023

Patra, A. K., and M. Lalhriatpuii. 2016. Development of statistical models for prediction of enteric methane emission from goats using nutrient composition and intake variables. Agric. Ecosyst, Environ. 215:89-99. doi:10.1016/j. agee.2015.09.018

Puchala, R., G. Animut, A. K. Patra, G. D. Detweiler, J. E. Wells, V. H. Varel, T. Sahlu, and A. L. Goetsch. 2012a. Effects of different fresh-cut forages and their hays on feed intake, digestibility, heat production, and ruminal methane emission by boer x spanish goats. J. Anim. Sci. 90:2754-2762. doi:10.2527/jas.2011-4879

Puchala, R., G. Animut, A. K. Patra, G. D. Detweiler, J. E. Wells, V. H. Varel, T. Sahlu, and A. L. Goetsch. 2012b. Methane emissions by goats consuming Sericea lespedeza at different frequencies. Anim. Feed Sci. Technol. 175:7684. doi:10.1016/j.anifeedsci.2012.03.015

Puchala, R., S. LeShure, T. A. Gipson, K. Tesfai, M. Flythe, and A. L. Goetsch. 2018. Effects of different levels of lespedeza and supplementation with monensin, coconut oil, or soybean oil on ruminal methane emission by mature Boer goat wethers after different lengths of feeding. J. Appl. Anim. Res. 46:1127-1136. doi:10.1080/09712119.2 018.1473253

Puchala, R., B. R. Min, A. L. Goetsch, and T. Sahlu. 2005. The effect of a condensed tannin-containing forage on methane emission by goats. J. Anim. Sci. 83:182-186. doi: $10.2527 / 2005.831182 x$

Reed, J. S. 1995. Nutritional toxicology of tannins and related polyphenols in forage legumes. J. Anim. Sci. 73:15161528. doi: $10.2527 / 1995.7351516 x$

Robbins, C. T., T. A. Hanley, A. E. Hagerman, O. Hjeljord, D. L. Baker, C. C. Schwartz, and W. W. Mautz. 1987. Role of tannins in defending plants against ruminants: reduction in protein availability. Ecology 68:98-107. doi:10.2307/1938809

Romero-Huelva, M., M. A. Ramírez-Fenosa, R. PlanellesGonzález, P. García-Casado, and E. Molina-Alcaide. 2017. Can by-products replace conventional ingredients in concentrate of dairy goat diet? J. Dairy Sci. 100:4500 4512. doi:10.3168/jds.2016-11766

SAS. 2011. SAS/STAT® 9.3 User's Guide. Cary, NC: SAS Inst. Inc.

Shen, J. S., Z. Chai, L. J. Song, J. X. Liu, and Y. M. Wu. 2012. Insertion depth of oral stomach tubes may affect the fermentation parameters of ruminal fluid collected in dairy cows. J. Dairy Sci. 95:5978-5984. doi:10.3168/ jds.2012-5499 
Steinfeld, H., P. Gerber, T. Wassenaar, V. Castel, M. Rosales, and C. de Haan. 2006. Livestock's long shadow: environmental issues and options. Rome, Italy: Food and Agriculture Organization of the United Nations.

Tomkins, N.W., S. E. Denman, R. Pilajun, M. Wanapat, C. S. McSweeney, and R. Elliott. 2015. Manipulating rumen fermentation and methanogenesis using an essential oil and monensin in beef cattle fed a tropical grass hay. Anim. Feed Sci. Technol. 200:25-34. doi:10.1016/j. anifeedsci.2014.11.013

Tovar-Luna, I., R. Puchala, T. A. Gipson, G. D. Detweiler, L. J. Dawson, T. Sahlu, A. Keli, and A. L. Goetsch. 2011a. Effects of night-locking and stage of production on forage intake, digestion, behavior, and energy utilization by meat goat does grazing grass/legume pasture. Livest. Sci. 140:225-245. doi:10.1016/j.livsci.2011.03.034

Tovar-Luna, I., R. Puchala, T. Sahlu, H. C. Freetly, and A. L. Goetsch. 2010. Effects of stage of lactation and level of feed intake on energy utilization by alpine dairy goats. J. Dairy Sci. 93:4829-4837. doi:10.3168/ jds.2010-3316

Tovar-Luna, I., R. Puchala, T. Sahlu, H. C. Freetly, and A. L. Goetsch. 2011b. Effects of level of feeding on energy utilization by angora goats. J. Anim. Sci. 89:142-149. doi:10.2527/jas.2010-3054
Tovar-Luna, R. Puchala, T. Sahlu, and A. L. Goetsch. 2017. Effects of gender and age on energy use by young Boer goats. Livest. Sci. 199:86-94. doi:10.1016/j. livsci.2017.03.016

Tsukahara, Y., T. A. Gipson, R. Puchala, T. Sahlu, and A. L. Goetsch. 2014. Effects of the number of animals per pen and length and time of automated feeder access on feed intake, growth performance, and behavior of yearling Boer wethers. Small Rumin. Res. 121:289-299. doi:10.1016/j.smallrumres.2014.09.003

Tsukahara, Y., R. Puchala, T. Sahlu, and A. L. Goetsch. 2016. Effects of level of brackish water on feed intake, digestion, heat energy, and blood constituents of growing Boer and Spanish goat wethers. J. Anim. Sci. 94:3864-3874. doi:10.2527/jas.2016-0553

Van Soest, P. J. 1994. Nutritional ecology of ruminants. 2nd ed. Ithaca, NY: Cornell University Press.

Van Soest, P. J., J. B. Robertson, and B. A. Lewis. 1991. Methods for dietary fiber, neutral detergent fiber, and nonstarch polysaccharides in relation to animal nutrition. J. Dairy Sci. 74:3583-3597. doi:10.3168/jds.S0022-0302(91)78551-2

Weimer, P. J. 2015. Redundancy, resilience, and host specificity of the ruminal microbiota: implications for engineering improved ruminal fermentations. Front. Microbiol. 6:296. doi:10.3389/fmicb.2015.00296 